\title{
O Diálogo Vertical Recíproco entre os Níveis do Ordenamento Jurídico Brasileiro
}

\author{
Adriano Fernandes Moreira
}

\section{INTRODUÇÃO}

O presente trabalho científico tem por objetivo promover um estudo acerca das relações que se podem estabelecer entre os níveis do ordenamento jurídico brasileiro, mais especificamente entre o direito constitucional o direito ordinário e o direito judiciário.

Para tanto, dentro do tema proposto, cumpre examinar a possibilidade de aplicação direta da constituição e o movimento de constitucionalização do direito ordinário, inclusive do privado. A questão está em determinar se são ou não corretos tais movimentos, pois ao Que tudo indica, negar a aplicação direta da constituição, prejudicando o interesse do ser humano no caso concreto, é restabelecer ao juiz, como nos tempos modernos, a condição de fiel e mecânico aplicador da lei. Se por outro lado, ocorrer respeito absoluto a constituição da república, com a aplicação da declaração de inconstitucionalidade, por exemplo, a concretização da justiça seria dificultada. Para encontrar uma solução, se farão algumas considerações neste singelo trabalho.

O tema se impõe pela sua atualidade e todos sabem que seu enfrentamento não é fácil. Alguns autores aduzem Que se deve fazer o máximo esforço para @ue as soluções judiciais sejam justas, pois com a adoção de constituições escritas passou-se pelas fases de declaração dos direitos e acesso aos direitos, até se chegar à fase atual de concretização dos direitos.

Ao final, da conjugação desses elementos, se ensaiarão breves linhas conclusivas, com uma abordagem que visará mais à síntese do conteúdo exposto, do que propriamente ao inovador, ao inédito. Porém, em todos esses momentos, não se abdicará de uma visão crítica dos diversos entendimentos, Quer sejam legais, doutrinários ou de nossas cortes de justiça. E o método a ser empregado será, sobretudo, o dialético, chegando-se, a partir do amálgama formado pela contraposição de teses, como dito, a conclusões temáticas. No Que tange à técnica de coleta de dados, utilizar-se-á, para tanto, a relativa à consulta de documentação indireta, com pesquisa documental e secundária, colacionando-se fontes da legislação e doutrina. 
Todavia, advirta-se ao leitor desatento do caráter limitado desta pesquisa, que de forma alguma visa esgotar o tema proposto, objetivando menos a glória pela imposição e edificação de posições pessoais, do Que o estampar da Questão a ser debatida, com vistas a despertar, de maneira humilde, o interesse pela matéria, frente aos seus consumidores.

Ao final, pretende-se demonstrar ser a constituição o suporte das legislações, e estas instrumentos indispensáveis no auxílio aos magistrados ansiosos por fazerem justiça no caso concreto. Em seguida, cogitar a existência de um fenômeno de complementaridade e respeito das relações entre os níveis ou planos do ordenamento jurídico, posto Que da realidade ontológica da pessoa, da família e da vida social ordinária surge uma força criadora Que se dirige ao nível mais elevado e volta rapidamente dando origem a um loopsem fim, entre os níveis ou planos do ordenamento jurídico.

\section{Capítulo 1 - Aspectos Gerais}

\subsection{Relaçóes do nível constitucional com o infraconstitucional}

Sob a perspectiva teleológica percebe-se que matérias antes disciplinadas no nível intermediário pela legislação ordinária agora foram elevadas ao nível fundamental e são tratadas pela constituição, ocorrendo a constitucionalização do direito ordinário, fato Que desperta a atenção de doutrinadores brasileiros' ${ }^{1}$, argentinos ${ }^{2}$, alemães ${ }^{3}$, italianos ${ }^{4}$ e portugueses ${ }^{5}$.

\footnotetext{
' V.g., SOUZA IúNIOR, Cezar Saldanha, Direito Constitucional, Direito Ordinário e Direito /udiciário. Porto Alegre: Cadernos do Programa de Pós-graduação em Direito - PPGD/UFRGS, n.I (fevereiro/2005); SARLET, ingo Wolfgang (Org.). A Constituição Concretizada. Porto Alegre: Livraria do Advogado, 2002; e, do mesmo autor, Constituiçáo, Direitos Fundamentais e Direito Privado. Porto Alegre: Livraria do Advogado, 2003; TEPEDINO, Gustavo (Org.). Problemas de Direito Civil Constitucional. Rio de Janeiro: Renovar, 2000; e, do mesmo autor. A parte Geral do Novo Código Covil Estudos na Perspectiva Civil Constitucional. Rio de laneiro: Renovar, 2003; MARTINS-COSTA, Judith (Org.). A Reconstrução do Diretto Privado. São Paulo: Revista dos Tribunais, 2000; NEGREJROS, Tercsa. Teoria dos Contratos: novos paradigmas. Rio de laneiro: Renovar, 2002.

${ }^{2}$ Cf. MAYÓN, Carlos A. Bases Consitucionales del Derecho Civi - Parte General. Buenos Aires: Lex, Tomo 1, 2001 e Congresso Mundial de Direito Constitucional. Quarta Comissão: Direito Humanos e Direito Privado. Comunicação n. ${ }^{\circ} 0$ I; Relações entre o Direito Constilucional e o Direito Civil. Evolução. Janeiro/2004.

${ }^{3} \mathrm{Cf}$. CANARIS, Claus Withelm. Direitos Fundanentais e Direito Privado. Trad. Ingo Wolfgang Sarlet et. at. Coimbra: Almedina, 2003.

${ }^{4}$ Cf. Pietro PERLINGIERl. Perfis do Direito Civil introdução ao direito civil constitucional. Rio de laneiro: Renovar, 2000.

${ }^{5}$ Cf. RIBEIRO, foaquim de Souza. Constitucionalização do Direito Cintl. Coimbra: Boletim da Faculdade de Direito da Universidade de Coimbra, v. LXXIV, 1998, p. 729-755.
} 
Essa interpenetração ou fusão tem provocado várias discussões no cenário jurídico. O fenômeno envolve o direito ordinário e inclusive o direito privado. Estamos diante de uma constitucionalização dos direitos ordinários e alguns estudiosos já falam em hiperconstitucionalização nos casos do direito administrativo e tributário.

Há um clima de instabilidade e insegurança e surgem, a cada dia, discussóes (lógicas) a respeito do futuro das relações entre o sobredireito (do grau superior ou fundamental), o direito ordinário (grau primário) e o direito das decisões jududiciais ou resoluçōes administrativas (do grau secundário). É difícil delimitar os caminhos a serem percorridos, pois em cada nível, seja dos fins últimos, seja dos fins próximos, temos um tipo diferente de racionalidade, de interpretação e de seleção.

Fácil perceber Que um valor só existe no plano fundamental do ordenamento jurídico. E não pode ser aplicado nos fatos, pelo direito, sem antes passar por um processo de mediação Que se fará por intermédio da legislação ordinária. Então, o normal e conveniente, dentro de uma visão integrada do ordenamento jurídico, é que o grau primário ou legislativo, ou nivel intermediário, por meio da elaboração de leis, seja responsável por tal mediação. Mas Quando isso não ocorre aparece o problema entre criador (legislador constituinte) e criatura (legislador ordinário), pois com a presença da constituição da república e a omissão do legislador ordinário, não se consegue iluminar o nível mais próximo, Qual seja, o do julgador. E assim, em face de inexistência da interpositio/egislatóris, ao legislativo é conferido um poder nunca antes visto.

Para alguns constitucionalistas, os civilistas deveriam ter apressado a aprovação do código civil brasileiro ao invés de ter deixado Que ocorresse a extensão da matéria normativa da constituição. O legislativo, por culpa desse movimento de constitucionalização, se vê cada vez mais sobrecarregado em sua tarefa de mediação. Por outro lado se abre o sistema jurídico brasileiro com cláusulas gerais e conceitos jurídicos indeterminados, dando um grande poder aos juízes.

Um grande problema é Que nem sempre os juizes são prudentes. Alguns se valem do jeitinho brasileiro e concretizam valores, outros, menos preparados, tentam aplicar a mesma técnica, mediante o uso absurdo da jurisprudência, para casos nada semelhantes. 
Alguns julgadores utilizam a aplicação totalmente assistemática e ideológica de valores constitucionaịs, Que na verdade, acabam se tornando uma imposição da opinião pessoal do juiz, sob a justificação de Que o faz em nome da constituição. Mas os juízes jamais deveriam decidir os casos controversos, com base em seu próprio julgamento, político ou ideológico. Nem é bom entrar nesta seara, pois é o grande problema dos processualistas, e diz respeito às fundamentaçôes ideológicas da sentençat.

\subsection{Múltiplas dimensóes do problema}

O tema é sem dúvida relevante e tem ocupado lugar de destaque na doutrina pátria de modo muito especial. Centenas de livros e artigos publicados. É possível perceber a inquietude dos operadores do direito. São feitas reflexões sobre: a) a relação entre política e direito ${ }^{7}$; b) fałhas e omissões do executivo e do legislativo ${ }^{8}$; c) hermenêutica ${ }^{9}$ e d) fusão da jurisdição ordinária e constitucional no poder judiciário ${ }^{10}$.

Surgem indagações sobre: (a) o Que se deve buscar na interpretação de um texto normativo; (b) Quais os seus limites da interpretação; (c) se a interpretação possui alguma função criadora ou modificadora do direito ou visa apenas a conhecer o teor da norma.

Quanto à possibilidade de concretização de valores materiais constitucionais, há muita divergência doutrinária. Alguns sustentam a total possibilidade de realização dos direitos fundamentais, não havendo limites ou barreiras, Que possam impedir o juiz de assim proceder. Uma segunda vertente sustenta a possibilidade remota de que os princípios e normas inseridas na constituiçăo possam modificar o direito ordinário somente em casos extremos, pois onde o processo político (legislativo e executivo) comete falhas ou se omite na implementação de políticas públicas e dos objetivos sociais nela implicados cabe ao poder judiciário tomar uma atitude ativa na realização desses finns sociais através da correição de prestações dos serviços básicos. Uma terceira corrente, menos radical, se dedica unicamente à tarefa de verificar de Que modo e segundo Que técnicas tornar-se-ia possível a aplicação dos postulados constitucionais no campo do direito ordinário.

6 Cf. Rui PORTANOVA. Motivaçốes ideológicas da sentença. Porto Alegre: Livraria do Advogado, 2003.

7 Cf. FERREIRA FILHO, Manoel Gonçalves. A Constituição de 1988 e a /udicialização da Pollitica. Revista da Faculdade de Direito da UFRS, v. 12, p. 189 e ss., 1996; e, do mesmo autor, Estado de Direlto e Constituição. Săo Paulo: Saraiva, 1988.

8 Cf. FACCHINI NETO, Eugênio. Reflexóes histórico-evolutivas sobre a constitucionalizaçãa do direito privado. In: SARLET, Ingo Wolfgang (Org). Constituiçäo, Direitos Fundamentais e Direito Privado. Porto Alegre: Livraria do Advogado, 2003.

9 Cf. BASTOS, Elisio. Interpretação Constitucional - A quem cabe a tarefa de concretizá-la? Revista de Direito Constituclonal e Internaciona/. São Paulo: Revista dos Tribunais, V. 4I, [s. d.] p. 241-254.

to SOUZA JÚNIOR, op. cit., p. 7-18. 
Se o juiz evitar a concretização de valores materiais constitucionais, privilegiando o sentido procedimental do texto constitucional, seu ato terá por conseQüência direito sociais não realizados e direitos fundamentais não respeitados. Se o juiz realizar tal concretização, garantindo a possibilidade do resgate desses direitos com o objetivo de proteger o cidadão e a sociedade incorrerá no risco de transformar o direito constitucional de valores em direito de ideologias da pior espécie.

E esse direito de ideologias esbarra no que é financeiramente possivel e na judicializaçăo da política. A doutrina clássica já reconhecia o princípio da inafastabilidade do controle judicial Que foi inscrito, a contrário senso, ainda na Carta de 1934, a Qual aduzia: "É vedado ao Poder Judiciário conhecer de Questões exclusivamente políticas" ". Mas a partir de 1946 foi enunciado claramente da seguinte forma: "A lei não poderá excluir da apreciação do Poder Judiciário Qualquer lesão de direito individual" (art. I $\left.41, \S 4,{ }^{0}\right)^{12}$. Tal princípio depreende-se também da legislação ordinária, sobretudo no código de processo civil:

"Art. 126. Ojuiz não se exime de sentenciar ou despachar alegando lacuna ou obscuridade da lei. No julgamento da lide caber-Ihe-á aplicar as normas legais, não as havendo. recorreráa analogia aos costumes e aos princípios gerais do direito."

\section{"Ant. 335. Em falta de normas jurídicas panticulares, ojuizaplicará as regras de experiência comum subministradas pela observação do que ordinariamente acontece e ainda as regras da experiência técnica, ressalvado, Quanto a esta, o exame pericial."}

Também esbarramos na separação dos poderes. Aqueles que não aceitam a concretizaçâo de valores materiais constitucionais aduzem Que caberia ao Poder Legislativo elaborar as leis e Que ao juiz não compete fazer lei ou julgar contrariamente a ela. Por outro lado o Legislativo do mundo pós-moderno não consegue acompanhar constantes mudanças sociais, sendo algumas legislações ordinárias, incompreensíveis, inaplicáveis e inaceitáveis em várias áreas.

O Direito Constitucional passou a tratar também de aspectos classicamente disciplinados pelo direito privado enunciando princípios e consagrando valores Que se aplicam também às relações entre os particulares.

\footnotetext{
1) Tema muito bem analisado pelo FERREIRA FILHO, op. cit, 192-193; e, do mesmo autor, A Constituição de 1988 e a judicialização da Política. Revista da Faculdade de Direito da UFRGS, v. 12, 1996, p. 189 197.

12 FERREIRA FILHO, Aspectos..., idem.
} 


\subsection{Pontes de liqação entre o público e o privado}

Para Cezar Saldanha Souza Junior ${ }^{13}$ é do privado que provêm os grupos de pressão, a opinião pública. Há uma inter-felação entre o direito público e o direito privado. Podemos falar em convergência entre um e outro e em publicização do direito privado e privatização do Direito Público. Ludwig Raiser ${ }^{14}$ sustenta a necessidade de o direito privado não perder a sua especificidade, ainda Que sofrendo o influxo das opçôes valorativas.

O Estado em certas situações deve respeitar a esfera íntima do individuo, deve ter a responsabilidade de proporcionar ações positivas, deve cobrar a participação do indivíduo e até mesmo submeter o indivíduo a suas vontades.

Ao longo dos anos se discute o tema abordado sobre os mais variados aspectos e sob as mais variadas denominações: a) direito civil constitucional; b) constitucionalização do direito civil; c) publicização do direito privado; d) privatização do direito público; e) conseqüências públicas do direito privado; f) reflexos dos princípios, diretrizes e direitos fundamentais constitucionais, no direito privado; g) hiperconstitucionalização do direito administrativo; h) sistema constitucional tributário; i) concretização da constituição; j) juzhumanização das relações privadas; l) método hermenêutico concretizante; e m) eficácia das normas constitucionais; n) direito constitucional, direito ordinário e direito judiciário.

${ }^{13} \mathrm{Cf}$. SOUZA JUNIOR, Cezar Saldanha. O Consensus no Constitucionalismo Ocidental. Tese de Doutorado. Săo Paulo: Faculdade de Direito da USP, junho de 1984. Aduz o mencionado autor: "Em contraposição ao público, o conjunto de relaçós no seio da comunidade, que refoge a esfera imperativa do inando e da obediência compốe o campo das relaçöes privadas, a esfera do privado ou, simplesmente o privado. Näo há como definir, senão por exclusão a esfera do privado pois as fronteiras säo extremamente variáveis, mudam conforme a época, o regine politico e os condicionanentos da realidade social. Como tudo em politica, os linites cntre o público e o privado também se sujeitam à divergência de opiniöes e conflitos, tratando-se de mais uma área alcançada por sua natureza polêmica. A /ixação dessa fronteiras depende, portanto de um mando tornado efetivo pela obediência. A matriz da classificação não éjuridica é polfitica. A esfera do público ć o domínio próprio do modo de existir politico do homem. A esfera do privado tende a ser o domínio das comunidades mais elementares. A dialética que se estabelece entre elas é muito viva. Na relação públicoprivado as posicóes parecem se inverter. $E$ do privado que nascem as liberdade a serem garantidas e protegidas pelo poder público. É do privado que surgem as demandas e as exigências - em um Estado intervencionista".

i4 RAIZER, Ludwig. O Futuro do Direito Privado. Revista da Procuradoria Geral do Estado. Porto Alegre: PGE, v. 9 (25). 1979. p. 11 e ss. Aduz o referido autor: "(..) a luz do princípio da dignidade da pessoa humana os juristas vêm desenvolvendo, no país e no exterior, uma novel linha de pensamento cientifico, reputando-o a base mesma do ordenamento positivo e efetuando a partir delc, a releitura de todos os institutos jurídicos. As preocupaçóes excessivas com os aspectos patrimoniais do relacionamento humano vão sendo, pouco a pouco solapadas e abandonadas, buscando-se a consirução de unia ciência juridica mais personalista, em que se prime näo inais pelo ter, mas pelo ser. A personalização das relaçöes jurídicas é tendência e imperativo de uma nova ordem juridico social, em substituição ao dogmatismo excessivo, centrado na concepção de conceitos e teorias abstratos, distantes da realidade humana e baldos de conteúdo de significąaro, enfim, de vida". 
De todas as abordagens chamam a atenção a da hermenêutica, a da concretização da constituição e a do direito constitucional, direito ordinário e direito judiciário. Por outro lado, a problemática da eficácia das normas constitucionais tratadas por Carlos Alberto Bittaris é um dos pontos de maior relevância no direito, assim como a interpretação jurídica trabalhada por Karl Larenz ${ }^{16}$.

\section{CAPítulo 2 - O Debate Pós-Moderno}

\subsection{O fenômeno da constitucionalização}

Uma constituição é fruto de todo um trabalho intelectual, social, político. A omissão do legislativo diante de matérias novíssimas acaba por enfraquecê-la sobremaneira. Vale ressaltar que o fenômeno da constitucionalização foi intenso Quando o código civil de 1916 já não se adequava aos anseios da realidade brasileira. E isso é mais uma prova da existência de uma energia criadora, originada na realidade ontológica da pessoa, da família, e da vida social ordinária, Que faz dialogar a realidade, o direito legislado e o direito enquanto expressão dos valores humanos mais elevados. Tudo isso gera um loop Que começa na base, atinge o topo, volta para base, e assim sucessivamente.

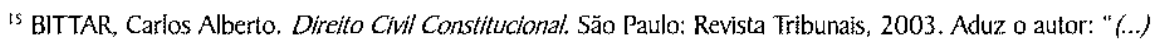
tudo parece girar em tomo da problemática da eficácia das normas constitucionais. Umas atingem imediatamente o ordenamento vigente, rompendo-o, enquanto outras, por sua natureza, ou por força de comando do próprio constituinte, tem seus efeitos postergados para outra etapa. Săo estabelecidos comandos para o legislador ordinário, para o juiz e demais interpretes, definindo horizontes, fixando balizas, estabelecendo contornos que governarão a ordem juridica do país. De outra plana, o constituinte indica expressamente como deseja sua aplicação. Em outros, traça diretrizes que devem govemar a interpretação sistemática efinalistica, em que se the definirá a respectiva tarefa Que, embora difícil, conta com nortes seguros na própria teoria da interpretação. Com a promulgação da Constituiçăo atinge-se a ordem jurídica, mudando-a. Novos princípios e regras vão provocar efeitos na ordem privada, a luz do respectivo alcance. Daí edita-se nova ordem privada ou se ajusta esta a seus' cânones conforme a profundeza das nuturas operadas. As leis ordinárias incompatíveis ou são substituidas ou são declaradas inconstitucionais. Nenhuma lei poderá nascer fora dos limites por ela imposto."

16. Sobre a interpretação e desenvolvimento judicial da lei e influência da lei fundamental veja: Karl LARENZ, Derecho Civit. Parte General. Munich: Editoriales de Derecho Reunidas, 1978, p. 84-101. 
O Código Civil e leis especiais atingidos estāo sofrendo o referido processo de reajustamento Que tem representado grande desafio ao legislador. $O$ direito civil da atualidade, relativizado, historicizado, pluralista, redesenha a dogmática em favor da tutela da dignidade da pessoa humana. Segundo Júlio César Finger ${ }^{17}$, tinha Que desaparecer o direito próprio do estado liberal clássico, centrado no individualismo e patrimonialismo que o caracterizou, Pietro Perlingieri ${ }^{18}$ afirma Que a categoria do ser não pode ser subordinada àQuela do ter, sendo necessário reler a legislação à luz da opção constitucional, na Qual se encontram limites insuperáveis no respeito aos direitos fundamentais da pessoa. Ludwig Raizer ${ }^{19}$ fala sobre a importância de conservar a força vital do direito privado como peça preciosa da ordem jurídica geral. Para Maria Amália dias de Moraes o movimento não passa de uma falsa Questão $0^{20}$.

Dando-se ênfase a ótica social e observada a relatividade na idéia formal de igualdade, o destaque dos elementos sociais impregnará o direito privado de conotações próprias. eliminando os resquícios ainda existentes do individualismo e do formalismo jurídico, para submeter o Estado Brasileiro a uma ordem baseada em valores reais e atuais, em Que a justiça social é o fim último da norma, equilibrando-se mais os diferentes interesses por elas regidos, a luz de uma ação estatal efetiva, inclusive com a instituição de prestações positivas e concretas por parte do Poder Público para a fruição pela sociedade dos direito assegurados.

O Que caracteriza, na diversidade de temas o conjunto de trabahos, é precisamente a metodologia civil constitucional com Que são enfrentadas as diversas matérias, fornecendo aos interessados, num fio condutor homogêneo, indicações para a solução de numerosos problemas de direito civil Que, postos na ordem do dia, reclamam solução interpretativa coerente com o sistema constitucional e com a dinâmica realidade cultural brasileira, através de um diálogo de respeito e complementaridade entre os níveis.

17 Cf. FiNGER, lúlio César. Constituição e Direito Privado: algumas notas sobre a chamada constitucionalização do direito civil In: SARLET, Ingo Wolfgang (Org). A Constituiçäo Concretizada: Construindo Pontes com o público e o privado. Porto Alegre: Livraria do Advogado, 2000, p. 85 e ss.

18 Cf. PERLINGIERI, Pietro. op. cit., p. 4.

19 RAIZER, op. cit, p. 29

20 MORAES, Maria Amália Dias de. A Constituição e o Direito Civil. Revista da Procuradoria Geral do Estado. Porto Alegre: PGE, v. 20 (48), 1993, p. 47. Aduz a autora: "é preciso advertir que o designado fenômeno da 'publicização' do direito civil é uma falsa questão. O que ocorre, en verdade, é que as relaçôes de ordem privada, as vicissitudes do tráfico jurídico em uma sociedade de massas, adQuirem tal expressão que a garantia de uma disciplina justa dessas relaçöes näo pode mais ser subestimada pelo Estado. É para determinar o Quadro c o padräo desta disciplina, que as constituiçóes modernas têm inserido em seus textos numerosas referências às categorias relacionais tradicionalmente só objeto de regulação no Código Civit'. Na p. '1, da citada obra, a autora cita R. Von Ihering: "uma idéia sedutora e apressada diviga o conceito da dependência completa do direito privado em relaçäo ao Estado, outrora, $c$ que só pouco a pouco aquele se liberta desta prisão. Consideraçóes já desenvolvidas conduzem a admilir precisamente o contrário, ou seja, a completa independência, na origem, do direito privado frente ao Estado. A falta de oposição não decorre do fato de o Estado dominar o direito privado, mas ao contrário, do fato de o dircito privado dominar o Estado. Assim, o direito privado não foi edifcado segundo o direito público, mas o Estado é Que se construíu segundo os principios do direito privado. Seria, pois, contrário a toda história admitir que o Estado tenha engendrado, ele próprio, o direito privado". 
No que diz respeito ao fenômeno constitucionalização do direito civil, é por demais óbvio Que várias obras jurídicas são anteriores a entrada em vigor do novo código. Portanto, no período de vacatio legis os magistrados não tinham outra opção se não concretizar valores materiais constitucionais que embora ausentes no código Beviláqua estavam presentes no na nova legislação.

Veja-se o absurdo, estava em trâmite no congresso nacional um projeto de código civil de 1975, depois de tamanha demora, por força da realidade ontológica da pessoa, da família e da vida social ordinária, foi necessário que a constituição de 1988 trouxesse a tona elementos do projeto de lei.

\subsection{Milhares de tribunais constitucionais}

$\mathrm{Na}$ Europa o acesso ao tribunal constitucional ocorre por meio do clássico controle de constitucionalidade. Na Alemanha e na Espanha depois Que o caso chega ao tribunal superior, há o recurso de amparo denominado verfasungsbecheverg (oue se assemelha ao nosso recurso extraordinário). Lá prevalece o espírito de prudência, experiência e meditação. No Brasil se instalou a cultura jurídica de que o juiz pode atuar como um tribunal constitucional. Tem-se, então, milhares de tribunaizinhos constitucionais, posto Que cada magistrado pode exercer o controle difuso de constitucionalidade.

A fusão das jurisdiçōes constitucional e ordinária é incompativel com o modelo Romano Germânico. Como bem demonstrada por Cezar Saldanha de Souza Junior ${ }^{21}$ só é possível tal fusão no comon law. Nos Estados Unidos da América as jurisdições estão fundidas no poder judiciário. $\mathrm{O}$ juiz em tal sistema tem o poder de testar os limites da lei e deve interpretar de acordo com as linhas que o tribunal constitucional acena. Mas a grande Questão é saber se o juiz poderia em um salto olímpico, e ultrapassando a legislação ordinária, ir direto a constituição esquecendo-se do nível ordinária.

O tema da atualidade se divide entre a construção da razão, a vontade legislativa e a combinação ideal entre razão e realidade. Não podemos desprezar o direito vivo. Serve muito a mensagem de Fernando Facury Scaff de Que: "a constituição brasileira está viva, embora alguns de seus preceitos ainda necessitem ser realizados em toda sua dimensão emancipatória para o povo brasileiro"22. E esta concreção da constituição irá acontecer nã proporção do amor e do respeito de seu povo, preservando-a e integrando-a em seu dia-a-dia.

${ }^{21}$ Cf. SOUZA IUNior, Cezar Saldanha. A supremacia do direito e seus modelos básicos. Porto Alegre: Is. n.), 2002.

22 SCAFF, Fernando Facury. Constitucionalizando Direilos. Rlo de laneiro: Renovar, 2003, p. 259 e s5. 
A forma de legislar, por mejo de cláusulas gerais e conceitos jurídicos indeterminados, e se deve acrescentar, com o manuseio dos princípios constitucionais no dia-a-dia do foro, confere uma função política ao juiz, objetivando a proteção de minorias e a concretização da igualdade material em relação aos seus direitos, ou melhor, aos direitos relativos à dignidade da pessoa humana.

É fato notório Que tais direitos vêm sendo subutilizados pelos interessados ou sendo desconhecidos a cotio e sem fim pelo Poder Público, o que não infirma a tese jurídica de que existem e estão disponíveis. Tal fato serve apenas para incitar os estudiosos do Direito a transitarem persistentemente por este tema e a buscarem em juízo o reconhecimento efetivo destes direitos postergados, até a consolidação de uma consciência nacional capaz de determinar a positividade fática destes direitos, ao menos Quando levados à apreciação jurisdicional.

\subsection{Necessidade de reforma política}

Para Cezar Saldanha Souza Junior "a fusão no mesmo órgão (o poder judiciário), da jurisdição ordinária e da jurisdição constitucional (monismo jurisdicional)" ${ }^{23}$ produz uma concentração de poderes no poder judiciário ordinário. É necessária uma profunda reforma política, inclusive com a separação das duas justiças, instituindo-se o tribunal constitucional.

O Judiciário também precisa rever a atuação de seus membros, juízes jovens, ousados, combativos e politizados, por muitas vezes mal selecionados. Em sua maioria, são bacharéis recém-formados, com pouca prudência e positivistas, seguindo alguns ensinamentos de Pontes de Miranda ${ }^{24}$. Por pertencerem a uma elite desprezam os seres humanos humildes, maltratam os advogados Que thes reclamam rapidez e se vergam aos políticos, mesmo sendo dotados das garantias constitucionais (vitaliciedade, inamovibilidade e irredutibilidade).

No legislativo os parlamentares, deputados e senadores, além da pouca (ou nenhuma) formação, tem preocupações outras Que não com o povo ou seu estado. Na verdade representam os interesses de uma minoria privilegiada. Estão em busca de jatinhos e contas na Suiça, e se esquecem de Que segundo o Estagirita: "a vida dedicada a ganhar dinheiro, é uma vida forçada, e a riQueza não é, obviamente, o bem Que se deve procurar, pois se trata de uma coisa útil, nada mais" ${ }^{25}$. Os parlamentares compram os votos de seus eleitores em campanhas milionárias. E recentemente a Câmara dos Deputados está envolvida no maior

23 SOUZA IÚNIOR, Direito Constitucional, Direito Ordinário e Direito /udiciário, p. 13.

${ }_{24}^{4}$ MiRANDA, Francisco Cavalcanti Pontes de. Comentários ao Código de Processo Civil, Tomo IV. Rio de laneiro: Forense, 1974, p. 294. Aduzia o autor: "ainda Quando o juiz decide contra legem scriptam, näo viola o direito, se a sua decisäo corresponder ao que se 'reputa' direito. Por isso, o juiz deve afastar-se do texto legal, deixando de aplicá-lo, para servir ao direito do scu momento, porque, com tal procedimento, atende aos dois ideais aparentemente inconciliáveis: o da fixidez e o da mutação".

${ }^{25}$ ARISTÓTELES. Ética a Nicomaco. São Paulo: Martín Claret, 200 J, p. 15. 
escândalo de corrupção, inclusive sob a suspeita de que deputados estariam vendendo sua participação no congresso para permitì a governabilidade ao poder executivo. Dentro deste Quadro caótico, muito válida a doutrina de Pietro Perlingier ${ }^{26}$ acrescentando que o Legislativo não atende, por muitas vezes, ao essencial e mínimo respeito à pessoa humana.

Pior acontece no executivo. Os detentores das chaves dos cofres públicos desviam Quantias exorbitantes. Deveriam ser fiscalizados por outros órgâos, mas estes se omitem mediante a divisão do dinheiro sujo. Também não semeiam a amizade, nem em época de campanha, Que se move por puro interesse. Deveriam ser conscientes da atualidade da filosofia aristotélica, a Qual aduz Que "a amizade entre os governantes e os governados depende da Quantidade de benefícios conferidos, pois um rei beneficia seus súditos quando, sendo um homem bom, cuida do bem estar destes tal eual faz o pastor com as suas ovelhas"27. E acrescenta Aristóteles: "efetivamente, onde nada aproxima os governantes dos governados não pode existir amizade, visto Que não há justiça"28.

$\mathrm{Na}$ sociedade, os indivíduos (esfera privada) viram litigantes, seres ambiciosos. individualistas, dotados de poucas virtudes. Todos perdem a capacidade de dialogar e, o que é pior, de perdoar, muito embora, como indivíduos religiosos, continuem a pedir em orações de pai nosso: e perdoai os nossos pecados, assim como nós perdoamos a Quem nos tem ofendido.

A ordem dos advogados do Brasil poderia ajudar, mas foi afetada e desestimulada pela crise. Os processos defendidos por seus membros se arrastam por anos, e nenhuma explicação se pode dar. Muitos advogados abandonaram a ética. Litigar por litigar virou um excelente negócio para muito, Quanto mais recurso se interpõe, mais dinheiro se ganha.

${ }^{26} \mathrm{Cf}$. PERLINGIERI, op. cit., p. 3. Aduz o autor: "(..) a história sobretudo nos últimos decênios, ajuda a compreender Que Quando o Poder Legislativo, acredita estar acima e além dela própria, impondo prescriçöes Que violam os direitos fundamentais da pessoa humana, termina uma ordem juridica legitina e começa uma autoritária, fundada na pura força. Nesta hipótese, resta ao jurista a alternativa: respeitar as normas, ainda que injustas ou moralmente il/citas - tome-se, como exemplo, as leis fundadas na distinção dos individuos em raças, sexo ou renda - fazendo coincidir a sua escolha ideológica com aquela do legislador; ou recusar-se a ser jurista, não mais exercendo no sistema a própria profissăo - operador do direito, magistrado, burocrata e se empenhando, eventualmente, em uma atividade de resistência contra as escolhas illegitimas do legislador. o jurisia é aquele que interpreta, individua e aplica as leis: no momento em que as desaplica, exerce uma atividade, às vezes, historicamente louvável, mas diversa daquela de jurista. Entretanto, mesmo esta argumentaçấo tem naturalmente os seus limites. Basta considerar a não sujeição de alguns juristas ao Poder Legislativo Quando este não atendeu ao essencial e mínimo respeito à pessoa humana. Na época do nazismo. uma parte da jurisprudência italiana e alemä, algumas vezes, soube colocar um freio, ainda que limitado, à atividade do Poder Legislativo aplicando restritivamente algumas normas - aquelas, por exemplo, que se inspiravam na distinção das pessoas com base na raça - ou interpretando extensivamente alguns princípios Que ainda existiam, até entâo, de maneira apenas forma no ordenamento."

${ }^{27}$ ARISTÓTELES, op. cit., idem.

${ }^{28}$ ARISTÓTELES, op. cit., idem. 
Os acadêmicos de direito não se preocupam mais com valores superiores do ordenamento, com princípios, com a rieueza Que se acumula na axiologia, na sociologia, no direito constitucional. Estão preocupados com concursos públicos, estâo em busca de bons salários e status de seus futuros cargos, mesmo Que não tenha vocação alguma para exercêlos. Seriedade, honestidade, competência, preocupação com o bom direito, são valores totalmente descartados. Poucos são os idealistas em busca de um mundo melhor, com melhores condiçôes sociais, mais igualdade, mais respeito ao bem comum e a pessoa humana.

Cezar Saldanha de Souza lúnioror ${ }^{29}$ se referiu às múltiplas dimensões do humano. A auto-realização humana, em sociedade, envolve uma pluralidade de áreas de atividade. Muitos não se deram conta deste importante aspecto e se esqueceram do verdadeiro sentido do direito e de seus papeis, como cidadãos na sociedade. Vêem o direito como um instrumento e produto dos Que detêm o poder. Não existindo mais os juristas revolucionários, Que ficam acima daeueles que estão no poder e defendem a causa dos fracos e oprimidos. Pelo Que tudo indica não se vive em uma situação de normalidade. Vive-se o dilema entre a justiça e a segurança ${ }^{30}$. E todos têm seus pensamentos reduzidos a valores monetários, concorrênciais e consumistas, incapazes de instituir a verdadeira solidariedade essencial à sobrevivência do homem.

Devemos levar em consideraçāo a idéia de finalidade do direito. Quando não se sabe a sua finalidade tudo fica mais difícil. Situações nunca devem ser manipuladas e o intelecto humano dever ser sempre usado para o bern da humanidade. A norma jurídica se eleva acima do caso concreto até uma justa medida, depois passa a ser errada. E a norma jurídica pressupóe uma situação de normalidade, pois em uma situação anormal a norma não tem validade.

Para Plínio Melgaré3! a pessoa humana emerge como pressuposto essencial, núcleo e vértice da normatividade jurídica. júlio César Finger ${ }^{32}$ acrescenta que o Estado democrático de direito é um Estado comprometido constitucionalmente com a realização efetiva dos direito fundamentais. Para tanto Eugênio Facchini $\mathrm{Neto}^{33}$ aduz que o Estado passa a intervir, de forma imperativa, em extensas áreas que antes eram deixadas ao livre jogo das vontades privadas.

29 SOUZA júNIOR, A supremacia,.., idem.

30 Cf. MELLO, Adriana Mandin Theodoro de. A função social do contrato e o princípio da boa-fé no novo código civil brasileiro. [s. /]: Revista Forense, nov./dez. 2002. Aduz a referida autora "Para garantir a justiça é preciso flexibilidade, Que pode ser mais bem alcançada através de cláusulas gerais. Mas o direito não pode ser formulado somente em cláusulas gcrais, poís assim a grau de certeza seria mínimo. Portanto, o legislador tem a árdua tarefa de flexibilizar o Direito sem abrir mäo da segurança jurídica e vive em busca do justo equilibrio entre flexibilidade e segurança, sob pena de criar um mundo justo, mas inviável, ou uma sociedade eficiente, mas injusta, Quando é preciso conciliar a justiça e a eficiência".

3 MELGARÉ, Plínio. A jus-humanização das relaçães privada: para além da constitucionalizaçăo do direito privado. Porto Alegre: Revista da Ajuris, n. ${ }^{\circ}$ 94, 2004, p. 231. Acrescenta o autor: "É o ser humano, o homem-pessoa, que se afirma como fundaniento ético substancial indisponfvel da ordem jurídica, formando a densidade jurídico-axiológica exigida por um efetivo estado democrático de direito."

32 FINGER, op. cit., p. 92.

33 FACCHINI NETO, op. cit, p. 29. 


\section{CONCLUSÃO}

Conforme se tentou demonstrar até aqui, há uma confusão generalizada, pois as instâncias inferiores têm sido obrigadas, a concretizar diretamente - e cada juízo a seu modo - os valores supremos do ordenamento, pois embora não existam mais campos de execução, perseguições e depurações, horrores semelhantes continuam a acontecer, e o Que é pior, sob o manto do direito. Milhares de pessoas morrem todos os dias, vítimas da violência, vítimas da desnutrição, vítimas da miséria, vítímas do descaso, vítimas do crime organizado e da corrupção.

O homem pós-moderno desenvolveu a capacidade de usar o seu intelecto para o mal. Os políticos pós-modernos têm, como aliados, grupos de estudiosos (em especial juristas) Que usam de suas potencialidades somente para assegurar que os horrores, decorrentes do desvio de verbas públicas continuem a acontecer, e sob o manto do direito.

Todos se vêem confrontados permanentemente com o problema da incerteza dos conteúdos do sistema jurídico. A fim de que a vida social não caia no caos, é necessária a dissipação das incertezas, e as regulações têm Que ter algum tipo de conteúdo. Quando especificam os conteúdos do sistema jurídico, os científicos têm que atingir um equilíbrio entre dois objetivos que apontam em direções opostas. Por uma parte, têm Que respeitar a estabilidade e, por outra, têm que procurar a flexibilidade requerida pelas circunstâncias.

Destarte, caminha-se para uma discussão que gira em torno do problema de se verificar de Que modo e segundo que técnicas tornar-se-ia possível aplicar os postulados constitucionais, sem ideologizar. Trata-se, também de uma questão de hermenêutica constitucional, tema pouco tratado pelos constitucionalistas brasileiros. Os princípios e normas Que regem a interpretação formam o objeto da hermenêutica jurídica, parte da ciência do direito que faz o estudo sistemático da interpretação. $O$ mundo deve abrir os olhos para o direito constitucional, sobre como deve ser a sua interpretação. A hermenêutica constitucional é muito importante. E não se pode renegar as diferenças existentes entre a jurisdição ordinária e a jurișdição constitucional.

A sociedade evolui aceleradamente. Se o direito não se ajusta ao seu ritmo, atua como um freio de desenvolvimento. Até os processualistas já notam Que o formalismo exacerbado é um meio de se denegar justiça. Quanto mais rápida é a troca, tanto maior é a flexibilidade que se requer do sistema jurídico. Esta responsabilidade pesa sobre aqueles Que tem a seu cargo a adaptação da lei às novas circunstâncias e sobre a ciência do direito, Que aclara os conteúdos do sistema jurídico. É lamentável que a maquinaria legislativa é demasiado pesada e lenta para poder responder com a suficiente celeridade aos pedidos de reforma. Pedidos estes, provenientes da força criadora Que vem do nível mais baixo e deseja atingir o nível mais alto, para novamente descer, num loop infinito, fazendo surgir uma tensão entre as normas e a realidade social, Que só será superada por meio do diálogo vertical entre os níveis do ordenamento jurídico brasileiro. 


\section{BIBLIOGRAFIA}

ARSTÓTELES. Ética a Nicomâco. São Paulo: Martin Claret, 200 I .

BASTOS, Elisio. Interprelação Constitucional: a Quem cabe a tarefa de concretizá-la? Revista de Direito Constitucional e InternacionalSão Paulo: Editora Revisla dos Tribunais, v $4 \mathrm{l}$.

BITTAR, Carlos Alberto. Direito CMil Constitucional São Paulo: Revista dos Tribunais, 2003.

CANARIS, Claus-Wilhelm. Direitos Fundamentais e Direito Privado. Trad. Ingo Wolfgang Sarlet et. al. Coimbra: Almedina, 2003.

COSTA, ludith Martins (Org.). A Reconstrução do Direito Privado. Sâo Paulo: Revista dos Tribunais, 2002.

DONNINI, Rogério Ferraz. A Constituição Da república e a Concepção Social de Contrato. Temas Atuais de Direito Civil na Constituição Federal in: NERY, Rosa Maria de Andrade; VANA, Rui Geraldo Camargo. São Paulo: Revista dos Tribunais, 2000.

FACCHINI NETO, Eugênio. Rellexões histórico-evolutivas sobre a constitucionalização do direito privado. In: SARLET, Ingo Wolfgang (Org). Constituição, Direitos Fundamentais e Direito Privado. Porto Alegre: Livraria do Advogado, 2003, p. $11-60$.

FERREjRA FILHO, Manoel Gonçalves. A Constituição de 1988 e a Judicialização da Política. Revista da Faculdade de Direito da UFRS, v. 12, 1996, p. 189-197.

. Aspectos Constitucionais do Direito Constituciona/Contemporâneo. São Pauko: Saraiva, 2003.

Estado de Direito e Constituiçăo. São Paulo: Saraiva, 1988.

FINGER, lúlio César. Constituição e Direito Privado: algumas notas sobre a chamada constitucionalização do direito civll, In: SARLET, Ingo Wollgang (Org). A Constituj̧̧ão Concretizada. construindo pontes com o público e o privado. Porto Alegre: Livraria do Advogado, 2000.

GRAL, Eros Roberto. A Ordem Econômica na Constituição de 1988. São Paulo: Malheiros, 2002.

HESSE, Konrad. Derecho Constitukionaly Derecho Priakb. Madrid: Editorial Civitas, 1995.

LARENZ, Karl. Derecho Civit. parte general. Munich; Editorial Revista de Derecho Privado, 1978.

MAYÓN. Carlos. A. Bases Consititucionales del Derecho Civif. Tomo I, P. General. B. Ajres: Lex, 2001.

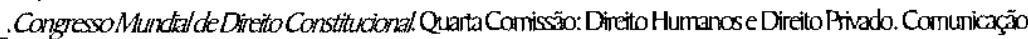
n. 01 : Relaçôes entre o Direito Constitucional e o Direito Civil. Evoluçẫo. Janeiro/2004.

MELGARÉ, Płínio. A jus-humanização das relaçōes privadas: para além da constitucionalização do direito privado. Porto Alegre: Revista da Associação dos fuizes do Rio Grande do Sul, Ano XXXI, n. ${ }^{\circ}$ 94, junho, 2004, p. 227-250.

MORAES, Maria Amália Dias de. A Constituição e o Direito Civil. In Revista da Procuradoria Geral do Estado. Porto Alegre: PGM, v. 20 (48), 1993, p. 45-54.

MORO, Sérgio Fernando. Por uma revisão da Teoria da Aplicabilikdade das Normas Constitucionais. Revista de Direito Constitucional e Internacional. São Paulo: Revista dos Tribunais, v. 37.

NEGREIROS, Teresa. Teoria do Contrato: novos paradigmas. Rio de Janeiro: Renovar, 2002.

PERLINGIERI, Pietro. Perfis do Direito Civil: Introdução ao direito Civil Constitucional. R... Renovar, 1997. PORTANOVA, Rui. Motivaçốsideológicas da sentença. Porto Alegre: Livrana do Advogado, 2003.

RAIZER, Ludwig. O Futuro do Direito Privado. Revista da Pracuradoria Geral do Estado. Porto Alegre: PGE, v. 9 (25), 1979, p. 11-30.

SARLET, Ingo Wolfgang. A Efkcicia das Dircilos Fundamentais. Porto Alegre: Livraria do Advogado, 2001. do Advogado, 2000.

. A constituição Concretizada: construindo pontes com o púbjico e o privado. Porto Alegre: Livraria

SARTI, Amir josé Finocchiaro. A Constitucionalização do Direito Civil. Revista /unídica. Porto Alegre: [s. ก.]. V. 312,2003 .

SOUZA JÚNIOR, Cezar Saldanha. A supremacia do direito e seus modelos básicos. Tese apresentada com requisito para concurso de professor titular de teoria geral do estado na Faculdade de Direito da USP. Porto Alegre: [s. n.], 2002.

. Direito Constitucional, Direito Ordinário e Direito/udiciário. Porto Alegre: Cadernos do Programa de Pós-graduação em Direito -PPGD/UFRGS, n. I, fevereiro/2005, p. 7-18.

TEPEDINO, Gustavo. Problemas de Direito Cinil Constitucional. São Paulo: Renovar, 2000.

. A parte geral do novo código civit. estudos na perspectiva civil-constitucional. Rio de faneiro:

Renovar, 2003. 